\title{
A performance da voz e a subjetividade na poesia contemporânea
}

Olliver Mariano Rosa

UFG

Goiandira Ortiz de Camargo

$\mathrm{CNPq}-\mathrm{UFG}$

\begin{abstract}
Resumo
Neste artigo, tratamos da relação que se estabelece entre o sujeito leitor e a subjetividade configurada no poema contemporâneo. Para isso, consideramos a performance vocal como instrumento de compreensão do texto poético, a despeito de hoje preponderar o uso do suporte impresso para sua publicação. Acreditamos que, na medida em que a feitura do poema implica a manipulação da materialidade sonora da palavra, a sua leitura precisa recorrer à escuta de uma voz, ainda que apenas como virtualidade. Constatamos, no entanto, que a realização vocal não dá a conhecer apenas o ritmo, o andamento e a entoação do verso; por meio dela, evidencia-se a presença da subjetividade que se manifesta na composição lírica. Nesse ponto, torna-se importante a observação de que a poesia abriga no mundo contemporâneo uma diversidade de configurações dadas por um sujeito criador múltiplo. Considerando isso, tomamos para estudo poemas de poetas contemporâneos, três portugueses, Fiama Hasse Pais Brandão, Ana Luísa Amaral e Manuel de Freitas, e três brasileiros, Francisco Alvim, Neide Archanjo e Claudia Roquette-Pinto. Com base na leitura desses poemas, propomos uma classificação das diferentes ocorrências do princípio subjetivo. Verificamos, por fim, de que forma a performance da voz entra em jogo com essas ocorrências.
\end{abstract}

Palavras-chave: poesia contemporânea; leitura; performance; voz.

\begin{abstract}
In this paper, we deal with the relationship established between the reader and the subjectivity set in contemporary poem. For this, we consider the vocal performance as a tool for understanding the poetic text, despite today prevail the use of printed media for publication. We believe that, to the extent that the making of the poem substantially involves the manipulation of the sound of the word, the reading need to resort to the listening of a voice, even if only as a potentiality. We note, however, that performing vocal does not demonstrate only rhythm, tempo and intonation of the verse; with her, the presence of subjectivity that manifests itself in lyrical composition becomes clear. At this point, it is important to mark that in the contemporary world poetry harbors a diversity of settings given by a multiple creator subject. Considering this, we study poems written by contemporary poets: three Portuguese, Fiama Hasse Pais Brandão, Ana Luísa Amaral and Manuel de Freitas, and three Brazilians, Francisco Alvim, Neide Archanjo and Claudia Roquette-Pinto. Based on these poems, we propose a classification of different instances of the subjective principle. We observe, finally, how the performance of the voice comes into play with these instances.
\end{abstract}

Keywords: contemporary poetry; reading; performance; voice. 
1. ZUMTHOR, Paul.

Introdução à poesia oral, 2010,

p. 179 , grifos do autor.

2. Lembramo-nos, particularmente, do vídeo Goyaz Poesia, gravado no Festival de Poesia de Goyaz, em 2006. Nele, aparecem entrevistas de poetas contemporâneos, entre eles, Carlito Azevedo, Alice Ruiz, Paulo Henriques Britto e Micheliny Verunshk.

\section{DUFRENNE, Mikel. $O$} poético, 1969, p. 12.

4. COHEN, Jean. Estrutura da linguagem poética, 1974, p. 49.

5. Vale mencionar, por exemplo, a dissertação de Glaucio Varella Cardoso, Poesia lida, poesia falada: poesia, performance e recepção aspectos teóricos e práticos, defendida em 2009, e o livro de Robert Pinsky, The sounds of poetry, cuja primeira edição é de 1998.

6. Empregamos o termo performance, como o define Paul Zumthor, em Performance, recepção, leitura.

7. ZUMTHOR, Paul.

Performance, recepção, leitura, 2007, p. 82-83.
"Toda poesia aspira a se fazer voz; a se fazer, um dia, ouvir”. ${ }^{1}$ É com essa aspiração que a poesia responde aos sucessivos eventos que constituíram e afirmaram a preponderância da expressão escrita sobre a oral. Esses eventos favoreceram que a dimensão sonora do fato poético fosse obliterada. Contudo, parece consensual, sobretudo entre poetas, que, se há um aspecto que caracteriza a poesia, é o vínculo indissociável entre seu som e seu sentido. ${ }^{2}$ Com essa compreensão, estudiosos já consideraram em suas descrições e análises do texto poético o ato de executá-lo vocalmente: por exemplo, Mikel Dufrenne diz que, "ao examinar a linguagem poética, não esqueceremos de que ela se destina à fala", ${ }^{3}$ e Jean Cohen, que, "realmente, a poesia é feita para ser declamada". ${ }^{4}$ Embora o gesto de produzir sonoramente o texto poético já tenha sido objeto de investigação, ${ }^{5}$ o pesquisador que o toma para estudo tem ainda de lidar com matéria incerta, principalmente, se opta por pensar esse gesto sob a perspectiva do sujeito que coloca em jogo sua própria voz e a expressão da subjetividade feita no e pelo poema.

Diante das obras de seis poetas de grande evidência na produção lírica mais recente, três portugueses, Fiama Hasse Pais Brandão, Ana Luísa Amaral e Manuel de Freitas, e três brasileiros, Neide Archanjo, Claudia Roquette-Pinto e Francisco Alvim, pensamos a relação do sujeito leitor com a poesia, em particular com a poesia contemporânea. Para isso, partimos do pressuposto já indicado no parágrafo anterior. Se a construção do poema implica um trabalho com a materialidade sonora, a sua leitura requer a escuta de uma voz, mesmo que esta se dê apenas como virtualidade. Por isso, buscamos ler os poemas tomando a performance ${ }^{6}$ vocal como instrumento de percepção e de análise. Não nos detemos, no entanto, apenas no aspecto sonoro. $\mathrm{Na}$ medida em que este se articula à produção de sentidos acionada por uma subjetividade, estendemos nosso estudo para a compreensão do modo como o feitio subjetivo se configura no poema contemporâneo, no qual os meios para expressão se pluralizam.

A carência de investigações mais constantes sobre a relação entre poesia e voz, especialmente com obras de língua portuguesa, dificulta a depuração da nomenclatura empregada. O próprio termo "voz" é aplicado de forma indiscriminada. O que se explica talvez porque a análise de poesia, muitas vezes, não parte de uma reflexão consistente sobre os fatores que interferem no(s) encontro(s) do leitor com o texto poético. Paul Zumthor, nesse sentido, chama atenção para metáforas, como "o poema diz" ou "o tom do autor", que, segundo ele, apelam "a uma vocalidade sentida como presença" e "manifestam um sentimento confuso dos vínculos naturais que existem entre a linguagem e a voz" . Para transformar essa imprecisão em algo produtivo no que se refere à poesia, propomos, à maneira de 
Zumthor, uma reflexão sobre o modo como a presença de uma vocalidade poética é sentida pelo leitor.

Esse mesmo autor, noutro livro, discorre sobre como por volta de 1150-1250 começa a se engendrar, ainda que lentamente, o modelo de predomínio da escritura sobre as potencialidades da voz. ${ }^{8}$ Esta perde aos poucos sua autoridade e sua disseminação nos usos, cedendo espaço à visualidade do texto escrito. Uma manifestação importante desse movimento é, no fim do período medieval e início da Renascença, o divórcio entre música e poesia .O vínculo que esta manteve com o canto na poesia antiga grega e latina e ainda na produção trovadoresca é desfeito. Entretanto, embora a poesia passe gradativamente a ter uma existência autônoma como arte escrita, a percepção da sonoridade (para não dizer musicalidade) permanece subjacente à compreensão dos poemas, tanto em sua produção quanto em sua recepção. Como afirma Eduardo Sterzi:

É, pois, como uma cicatriz de sua mais remota pré -história que a lírica continua a trazer a música em si ao menos como virtualidade; por mais obstinada que seja sua emancipação da música e da voz, por mais que se dirija a um estado de pura escrita, conserva sempre uma nostalgia da música e da voz, e em certa medida até do gesto que a vinculava à dança. ${ }^{9}$

Evidencia essa permanência a alusão recorrente que os discursos sobre a natureza do texto poético fazem ao aspecto sonoro. Esses discursos muitas vezes consideram que a presença do som, ainda que apenas em potencialidade, constitui elemento definidor da poesia. No romantismo, Hegel assevera que ela, "pelo seu próprio conceito, é essencialmente uma arte sonora”. ${ }^{10} \mathrm{O}$ filósofo diz que a poesia agrega às palavras o elemento do tempo e o do som e, em seguida, afirma que a escrita destitui a palavra de seu conteúdo espiritual e, "em lugar de nos dar a palavra sonante e a sua duração temporal, confia no nosso hábito para introduzir no que vemos a sonoridade e a duração". ${ }^{11}$ Aqui nos parece haver a indicação de um aspecto da relação que o leitor estabelece com o poema ao lê-lo. É preciso que o texto poético seja vocalizado para que seja percebida sua constituição material. No entanto, a composição lírica não é feita somente de som, nela se expressa uma subjetividade criadora - à qual Hegel confere centralidade e preponderância. Se na recepção do poema desempenhamos uma participação ativa para a realização de sua potencialidade sonora, estabelecemos ainda contato com a presença subjetiva que ali se instaura.

Chamamos atenção para o comentário de Hegel por conta de sua pontualidade em tratar do assunto. Entretanto, o recurso à vocalização se afirma como prática articulada à recepção
8. Idem., A letra e a voz, 1993, p. 26-28.

9. STERZI, Eduardo. Da voz à letra, 2012, p. 166.

10. HEGEL, Georg W. F. Curso de estética, 2010, p. 435.

11. Ibidem, p. 435. 
12. VALERY, Paul. Le coup de dés: lettre au directeur des Marges, 1957, p. 623.

13. Idem., Au hasard et au crayon, 1960, p. 637.

14. BERRY, Fancis. Poetry and the physical voice, 1962, p. 34. "Embora suponhamos que os poetas modernos componham silenciosamente, também supomos que, ao compor, eles registrem o que experienciam para si como som vocal, normalmente suas próprias vozes por mais que idealizadas. Mais completamente, poderíamos sugerir que eles registram a dupla experiência do ouvir e do dizer" (tradução nossa).

15. ECO, Umberto. Lector in fabula, 2008, p. 11.

16. Ibidem, p. 37. do texto poético também em contexto posterior, diverso ao do período romântico. Temos um bom exemplo quando Paul Valéry relata ter ouvido o "Lance de dados"do próprio Mallarmé, que se pôs a ler 'd'une voix basse, égale, sans le moindre 'effet', presque à soi-même”. ${ }^{12}$ Para Valéry, a neutralidade de tom, a ausência de artifício, seria o mais apropriado para proferir aquela obra poética. Nesse momento em que o vínculo entre sujeito criador e criação é posto em questão, considera-se ainda que a voz, se associada de forma conveniente à poesia, é capaz de expressar as "harmonias" do texto poético e, diríamos mais, os elementos subjetivos que nele surgem.

O mesmo Valéry escreve: "Le poème - cette hésitation prolongée entre le son et le sens". ${ }^{13} \mathrm{O}$ poeta-crítico coloca par a par, em sua caracterização do poema, a produção de sentidos e a constituição sonora. A definição indica que não há dúvida de que a referência à sonoridade é parte necessária da reflexão sobre o fenômeno poético. Entretanto, o que notamos é que escapa, muitas vezes, a essa reflexão o fato de que o som do verso é dado à percepção por uma voz, que não é nem única nem perene, porque emana de um corpo sujeito a vicissitudes. Aquele que murmura o verso para si sente uma vibração no próprio corpo, aquele que diz para uma audiência faz com que a vibração se propague pelo espaço e pelo corpo do outro. A voz participa na expressão da força da linguagem poética. À produção vocal, associa-se o poder das palavras, moduladas de forma a dizer e, ao mesmo tempo, a produzir determinados sentidos. Nesse ponto, chama a atenção o que diz Francis Berry: "though we suppose that modern poets compose silently, we also suppose that in composing they record what they are inwardly experiencing as vocal sound, usually their own voices however idealized. More completely, we could say they record the double experience of hearing and saying" ${ }^{14}$ Talvez a volatilidade do elemento vocal em performance tenha influenciado o número reduzido de pesquisas que o tiveram ou tem como objeto. Quando os estudos literários se voltam para a atividade da leitura sob a perspectiva do leitor, esse obstáculo torna-se um ponto de partida.

Eco define o texto como máquina preguiçosa que solicita a seu receptor um movimento cooperativo para preencher lacunas de sentido deixadas pelo emissor. ${ }^{15}$ Se "todo texto quer que alguém o ajude a funcionar", ${ }^{16}$ não é errado considerar que a poesia também se inclui nessa descrição. Entretanto, acreditamos que ela peça ao leitor uma participação mais efetiva, para atuar não apenas na atualização dos conteúdos, mas também na realização das sonoridades. Eco diz que o texto conjectura um destinatário, que não se identifica, porém, a alguém que exista concretamente, que possa ser identificado empiricamente. Embora, nesse sentido, o poema não se destine 
a um indivíduo em particular, ele parece requerer uma determinada fonia, como se solicitasse uma voz para proporcionar adequadamente a percepção da materialidade sonora que o constitui. Trata-se de um texto que, se postula cooperação à ordem dos significados, articula a ela, de forma mais ostensiva que na prosa, a produtividade na ordem dos significantes.

O destinatário do texto poético é, assim, agente de interpretação e, igualmente, agente de vocalização. Como assegura Zumthor: "todo texto poético é performativo, na medida em que aí ouvimos, e não de maneira metafórica, aquilo que ele nos diz. Percebemos a materialidade, o peso das palavras, sua estrutura acústica e as reações que elas provocam em nossos centros nervosos". ${ }^{17} \mathrm{Da}$ virtualidade à atualidade, o poema é uma entidade irrealizada em dois eixos: da leitura, como decodificação em direção à compreensão dos sentidos com base nos sinais gráficos, e da vocalização, como expressão de suas relações sonoras. São modalidades de cooperação que se completam. A fruição da poesia não prescinde de sua execução sonora, mesmo que esta não seja feita diante de um público, mas, em baixo volume de voz, do leitor-vocalizador para si, ou apenas como produção interior dos sons. Zumthor diz que a experiência com o texto poético é, sobretudo, da ordem do sensível, pois o poema mobiliza um conhecimento que, ludicamente, se faz corpo. ${ }^{18}$ Por essa razão, o autor acredita que mesmo a leitura de poesia que se detém na visualidade da página cumpre um grau performancial, ainda que mínimo. $\mathrm{O}$ ato de dizer poesia declara a condição de performance inerente à leitura de poemas e põe em evidência o jogo que eles propõem, oferecendo à percepção "a ordenação rítmica ou simétrica da linguagem, a acentuação eficaz pela rima ou pela assonância, o disfarce deliberado do sentido, a construção sutil e artificial das frases, [...] manifestações do espírito lúdico" que surgem na linguagem poética. ${ }^{19}$ Ao inscrever o poema numa duração e situá-lo no espaço de seu próprio corpo, o leitor se reconhece e se afirma como intérprete, em dois movimentos indissociáveis: o preenchimento de lacunas semânticas e a vocalização, que incorpora à matéria poética a subjetividade de uma voz.

Dizer um poema é necessariamente interpretá-lo. Mortimer Adler e Charles Van Doren, no livro $A$ arte de ler, definem, como etapa para a compreensão da poesia lírica, sua realização sonora pelo leitor, considerando que "o próprio ato de pronunciar as palavras obriga-o a entendê-las melhor”. ${ }^{20}$ $O$ verso, além de indicar percursos de sentido, também solicita que se identifiquem os traços de sua configuração sonora. Cohen, por exemplo, descreve como o poema escrito, com a alternância entre tipos gráficos e espaços em branco, oferece para a declamação as oscilações entre sons e silêncios. ${ }^{21}$ Muitos autores, quando se ocupam da transmissão vocal de poesia,
17. ZUMTHOR, Paul.

Performance, recepção, leitura, 2007, p. 54.

18. Ibidem, p. 77.

19. HUIZINGA, Johan. O jogo e a poesia, 1996, p. 147.

20. ADLER, J. Mortimer; VAN DOREN, Charles. $A$ arte de ler, 1974, p. 220.

21. COHEN, Jean. Estrutura da linguagem poética, 1974, p. 49. 
22. MOISÉS, Massaud. Ritmo, 1988, p. 446-448.

23. BOSI, Alfredo. Frase: música e silêncio, 2000, p. 103.

24. PAZ, Octavio. Verso e prosa, 1982, p. 82.

25. BOSI, Alfredo. Frase: música e silêncio, 2000, p. 112. se detêm na constituição do ritmo, do qual falaremos com o intuito de demonstrar como a vocalização poética pode ser empregada para compreensão de categorias de descrição e análise do texto poético.

O ritmo ganha evidência na performance vocal como causa e não efeito das escolhas estruturais (medida dos versos, extensão das estrofes, posição dos acentos) e escolhas fônicas (rimas, aliterações, assonâncias, repetições, onomatopeias). Essas escolhas adquirem sua realidade rítmica quando nelas se introduzem, pela expressão vocal, sonoridade e tempo. Nota-se aqui a diferença entre ter o poema em sua visualidade gráfica e ouvi-lo. Diferença que se amplifica, sobretudo na poesia moderna e contemporânea, em que encontramos um ritmo irregular e diversificado, que joga com a tensão entre possibilidades. Nesse sentido, na relação com o corpo, "ritmo", mais que metáfora da regularidade dos movimentos biológicos, é o termo que condensa a transformação que a linguagem poética sofre quando incorporada por uma voz que profere o poema.

"Ritmo" - do grego rhythmós, movimento regrado e medido, cognato de rheîn, fluir - designa, na música, sequência sonora uniforme, e, na poesia, alternância de sílabas dotadas de uma energia diversa. ${ }^{22}$ Dessas definições, podemos depreender três modalidades, a saber, duração, movimento e força. São essas modalidades, em suma, que se tornam evidentes quando o verso é investido pela realidade de uma voz. No texto poético em suporte escrito, vemos apenas rastros. $\mathrm{O}$ impulso rítmico se apresenta com sua totalidade somente quando o poema é realizado (ou pensado) sonoramente. Dessa maneira, um verso destacado de seu contexto, mesmo que escandido, diz muito pouco ou nada do conjunto rítmico que ele integra - por essa configuração total, metro não equivale a "ritmo".

Cada poema surge de uma cadência rítmica que lhe é própria. As diferentes escolhas de que o verso é resultado, são, no entanto, posteriores a determinados movimentos rítmicos, "que nascem na linguagem do corpo, na dança dos sons, nas modulações da fala". ${ }^{23} \mathrm{~A}$ diferença entre a polirritmia ritual do primitivo, a regularidade do clássico, e a heterogeneidade do moderno, surge numa relação dialética do impulso do indivíduo com o pulso de um tempo. Não se trata de buscar a origem primeira do "ritmo". Falamos de origem, pois essa é a condição que assume o corpo que, na performance, empenha sua voz e qualifica a força rítmica, com um andamento (duração) e certa entoação (movimento).

Segundo Paz, o ritmo "se dá espontaneamente em toda forma verbal, mas só no poema se manifesta plenamente". ${ }^{24}$ Para Bosi, "o ritmo é um modo de força”. ${ }^{25} \mathrm{O}$ autor afirma que, 
na composição poética, o uso da alternância faz supor a aplicação inconsciente de um princípio ciclóide, 'orgânico', da energia vocal. O ritmo, enquanto periodicidade, teria este sentido: ser presença sonora da Força, ser Vontade, ser o Desejo no seu eterno retorno. O ritmo não se limita a acompanhar simplesmente o significado do poema: arrasta-o para os esquemas do corpo. ${ }^{26}$

Para se chegar a essa compreensão fenomenológica do que seja o ritmo, é importante se partir, como sugere Goldstein, "da escansão [...] ficando só a cadência e a alternância entre sílabas fortes e fracas" ${ }^{27}$ Não se trata, no entanto, apenas de simplesmente esquartejar o verso, procede-se antes a uma análise que se vale conscientemente da contagem de sílabas poéticas e da marcação dos acentos e que, em nenhum momento, perde de vista seu objetivo último, a compreensão. O próprio Manuel Bandeira nos coloca diante dessa concepção, quando diz que "para salientar o ritmo se têm valido os poetas, nos vários idiomas, de recursos formais como sejam os acentos de intensidade, os valores de sílabas (quantidade), as rimas, a aliteração, o encadeamento, o paralelismo, o acróstico, o número fixo de sílabas". ${ }^{28}$ Ignorar esses recursos, certamente, reduz o número de caminhos para que se trace um percurso analítico consistente que sirva para uma performance vocal condizente com o poema.

Nesse sentido, Bosi põe em cena ainda as noções de andamento e de entoação, diferenciando-os da alternância de forças. $\mathrm{O}$ autor define andamento como marcação subjetiva das células rítmicas, o que conduz o ritmo à sua constituição no todo significativo do poema. ${ }^{29}$ Trata-se da qualificação do tempo de execução, da velocidade com que se vocaliza o verso. Proferi-lo de modo mais pausado ou mais acelerado importa à sua significação. Sobre esse aspecto, concordamos com a ideia defendida por Brik, no texto "Ritmo e sintaxe", de que é possível se perceber o movimento rítmico de um verso somente se ele for considerado em sua integração no poema. ${ }^{30}$ Já a entoação, além de evidenciar a linha melódica das frases, faz com que estas sejam mais que o metro ou a pauta acentual ao tornálas objeto de uma intencionalidade. Nesse plano, adquirem prioridade as pausas retóricas, a duração e a intensidade da pontuação e a força enfática dada, por exemplo, às palavras propulsoras de sentido. Cada parte do poema adquire forma e peso em um corpo, para o qual um verso, uma expressão ou um termo torna-se expansão em forma de som, som em forma de voz. "Não somente o conhecimento se faz pelo corpo, mas ele é, em seu princípio, conhecimento do corpo". ${ }^{31}$ Quando associa uma matéria entoacional à linguagem poemática, o sujeito vocalizador compreende seus limites corporais.
26. Ibidem, p. 111-112.

27. GOLDSTEIN, Norma

Seltzer. Versos, sons, ritmos, 1986, p. 23.

28. BANDEIRA, Manuel.

A versificação em língua portuguesa, 1997, p. 533, grifos do autor.

29. BOSI, Alfredo. Frase: música e silêncio, 2000, p. 105.

30. BRIK, Ossip. Ritmo e sintaxe, 1971, p. 132-133.

31. ZUMTHOR, Paul.

Performance, recepção, leitura, 2007, p. 78. 
32. AGAMBEN, Giorgio. O autor como gesto, 2007, p. 62.

33. FRIEDRICH, Hugo. Estrutura da lírica moderna, 1978, p. 36-37.
A longa exposição sobre as particularidades do ritmo poético denota duas implicações. Primeira, a reflexão sobre o estrato sonoro e suas modalidades de construção e expressão são objeto constante no estudo de poesia. Segunda, a questão da subjetividade lírica, que, na performance do dizer, como podemos notar pelas relações que se estabelecem entre os corpos em jogo, se conjuga à subjetividade de uma voz, ainda permanece por se fazer.

Com o romantismo, a subjetividade moderna se afirma e a poesia, como outras formas artísticas, se constitui foro por excelência de manifestação da dimensão subjetiva. Considerando isso, podemos pensar que a execução vocal de um poema atualiza essa manifestação quando empresta a ela uma forma sonora. O princípio subjetivo não se configurou, no entanto, sempre do mesmo modo. Na poesia romântica - ressalvas feitas a poetas alemães e ingleses -, esse princípio se instituía sob a face de um sujeito lírico uno e centrado. Os românticos pretenderam uma coincidência entre o eu que se pronuncia no poema e o eu que o escreve. Seria possível sugerir que o dizer de poesia conferia presença à voz do poeta. Devemos esclarecer essa afirmação. Por mais que não possamos tomar o poema como expressão exata do indivíduo criador em sua condição civil, a considerar as afirmações de Agamben, ${ }^{32}$ dizemos que, no contexto do romantismo, o lugar que o autor instaura com o gesto do texto tem fronteiras mais bem definidas, pondo as regras do jogo mais claramente ao leitor. Com a despersonalização da voz poética, inaugurada por Baudelaire,,$^{33}$ o sujeito lírico não se apresenta mais com demarcações tão claras. A vinculação simples e direta entre sujeito poético e sujeito empírico se inviabiliza. Com a produção da tríade da modernidade - Baudelaire, Rimbaud e Mallarmé -, já não se pode dizer com segurança qual é a identidade do eu que se afigura no poema, isso quando esse eu ainda se manifesta. Nas composições líricas contemporâneas, herdeiras dos avanços vanguardistas, a subjetividade assume caráter múltiplo, se compõe e se decompõe em fragmentos variegados. A cada poema, se instaura uma subjetividade diversa, que diz e se diz, e, assim, assume uma voz, atravessada por outras vozes, ou vozes-outras: a voz da língua, a voz do poeta, a voz da obra. Para compreender as implicações do processo de vocalização, colocamos, entre essas vozes, a voz do leitor, que ao dizer poesia toma parte na produção dos sentidos, na execução dos sons e, também, na expressão do elemento subjetivo.

A leitura das obras poéticas demonstrou que, embora múltiplas, as manifestações da subjetividade lírica revelam feições recorrentes. Resolvemos agrupar as ocorrências semelhantes em quatro categorias, que chamamos de instâncias - termo que nos serve tanto por dar o sentido de divisão em ambiências 
como por caracterizar algo na iminência de acontecer: vozes do "eu"; vozes para o "tu"; vozes sobre o "ele" e, por fim, vozes da ausência - designações elaboradas com base no ensaio "As três vozes da poesia", de Eliot. ${ }^{34}$

A cada instância, a relação do intérprete com o poema (em seu aspecto semântico- sonoro) se modifica. De um "eu lírico" marcado linguisticamente à palavra poética que se apresenta apenas como experimentação de linguagem, o contrato entre subjetividade lírica e expressão vocal se torna menos declarado, há uma variação no engajamento da voz que se diz em performance com a voz que se manifesta no enunciado poético. Isso se evidencia em poemas que, na configuração da subjetividade, tornam significativa a hesitação entre uma instância e outra. Priorizaremos os exemplos que favoreçam a compreensão das instâncias que ora apresentamos, dando ênfase a aspectos relacionados à produção vocal.

$\mathrm{Na}$ primeira instância, das vozes do "eu", o sujeito da enunciação lírica tem sua presença marcada linguisticamente nas formas verbais e pronominais. Sua figura se instaura de imediato no poema sob o aspecto de três vozes: a voz do sujeito tradicional, centrado no "eu"; a voz do sujeito plurarizado, estendido ao "nós"; e, por fim, a manifestação do sujeito fingido, um "eu” ou um "nós” que se coloca sob uma máscara. Com a voz do "eu", a marcação linguística exibe sem mais demora a figura do sujeito. Essa figura, no entanto, permanece cercada de ambiguidade. Embora o "eu" se pronuncie explicitamente, desconhecemos sua identidade. Para Jakobson, é justamente o elemento ambíguo que caracteriza a poesia, elemento que não envolve apenas a mensagem, mas também seu emissor e seu receptor. ${ }^{35}$ A configuração da incerteza permite a suspeita de que a presença de dados autobiográficos do autor determine a produção dos poemas. Entretanto, se há coincidências entre sujeito lírico e sujeito empírico, não é previsto no contrato de leitura sua confirmação, como nos diz Martelo. ${ }^{36}$ De todo modo, no dizer de poesia, a situação se torna outra. $O$ intérprete dá corpo e voz ao sujeito que se pronuncia no poema e se, com isso, não desfaz a ambiguidade, confere a ela uma nova configuração. A vocalização (re)instala a interface comunicativa da poesia, colocando em relação aquele que diz o poema e uma audiência. Bajard chama atenção justamente para o fato de que o gesto de proferir o texto literário significa investi-lo de outras linguagens e conduzi-lo a um plano ostensivo de comunicação. ${ }^{37}$ Nesse sentido, emprestar a voz ao texto poético implica assumir e, ao mesmo tempo, atravessar o ethos confabulado pela subjetividade lírica. Ethos, como define Maingueneau, é a imagem dos sujeitos engendrada discursivamente durante o processo de interação. ${ }^{38}$
34. ELIOT, T. S. As três vozes da poesia, 1972, p. 129.

35. JAKOBSON, Roman. Linguística e poética, 1974, p. 149-150.

36. MARTELO, Rosa

Maria. Reencontrar o leitor, Relâmpago, 2003, p. 48-49.

37. BAJARD, Elie. Ler e dizer. compreensão e comunicação do texto poético, 1999, p. 111-112.

38. MAINGUENEAU, Dominique. A propósito do ethos, 2008, p. 16-17. 
39. HAMBURGUER, Käte. $A$ lógica da criação literária, 1986, p. 168, grifo da autora.

40. BRANDÃO, Fiama Hasse Pais. Obra breve: poesia reunida, 2006, p. 550.
As marcas textuais da subjetividade delimitam o espaço de engajamento tanto na primeira quanto, como veremos, na segunda instância. $\mathrm{O}$ poema propõe a seu intérprete um vínculo mais explícito com o sujeito lírico, porque "experimentamo-lo como o enunciado de um sujeito-de-enunciação". 39 A relação se estabelece por um contrato manifesto. A voz admite para si uma identidade ao pronunciar "eu”. Requer-se que haja cumplicidade entre recitador e poema recitado. Trata-se, como sugerimos no parágrafo anterior, de in-corporar o ethos ali configurado. A voz se diz ao dizer, tal como se define o sujeito no poema "Sopro":

Os meus poemas reunidos no seu todo
são o meu som. O meu sopro
está neles, não está a boca que os soou.
Fazer os poemas, através da vida,
é pegar em meus gritos emudecidos
para que fiquem, melódicos, em papéis. ${ }^{40}$

Quando, diante de um público, o vocalizador torna audível a voz desses versos, ele se coloca na posição do "eu" que distingue "seu" movimento de criação como algo que se faz "através da vida", embora investir de sopro o som implique, pela modulação poética do mundo das experiências, apagar a contingência da "boca que o soa" e, ainda, emudecer os "gritos” reais para torná-los arte melódica. Os versos longos impõem à performance vocal um andamento lento, que é determinado também pelas pausas impostas da pontuação em pontos e vírgulas. Os hendecassílabos, que predominam, sugerem ainda um tom elevado para a elocução - embora "o meu som" e "o meu sopro" surjam numa redondilha maior. Esses aspectos determinam a inflexão dada aos versos; a ela, no entanto, importa, sobretudo, a presença marcante do eu, reforçada pela insistência do pronome possessivo. A assonância em "s" que percorre todo o poema assoma à voz do vocalizador que se torna a voz do sujeito lírico.

O sujeito pluralizado, ainda na primeira instância, modifica o pacto de interpretação, ao incluir o outro, ou, em muitos casos, ao simular a participação do outro na expressão do princípio subjetivo. Ao se vocalizar um poema em que se enuncia um "nós”, o outro é convidado a integrar o dizer. Forja-se uma identificação para sustentar uma identidade. Nesse sentido, o vocalizador precisa observar que, ao proferir um poema como "QUASE ESTUDO DE POESIA", de Ana Luísa Amaral, ele se declara como a voz do poema o faz e inscreve também o ouvinte nessa declaração:

Em relação a isso, temos dito: 
um elefante azul,

um pássaro de penas tão brilhantes

que a prata: imitação

E a solidão

a invadir os nervos todos

desta mão

direita. A minha mão.

Sobretudo polegar

e indicador,

no sítio em convergência

de caneta

Em relação a isso,

não dissemos: um elefante,

por mais que seja azul,

pode não ser poeta

Numa gaveta,

o resto: avesso a solidão.

Mas célula tão velha

que a unha se desprende

e cai no chão

Em relação a isso,

faltará dizer:

o ponto mais fulcral

da convergência

não pode ser ciência.

É $\operatorname{ser}^{41}$

A alternância entre a forma plural e a forma singular da marcação das pessoas em jogo cria uma espécie de diálogo, que inclui e, ao mesmo tempo, exclui o alheio. Fala-se em nós, mas o que persiste é a solidão. Aqui observamos novamente uma voz, ou uma modulação desta, que indica como um ser se faz poeta: pela imitação solitária, que envolve, no ato da criação, deixar o que é resto e convergir o que, dos nervos da mão, pode seguir para o fio da caneta. O vocalizador precisa perceber que a simplicidade do último verso condensa a fluidez de todo o poema, dada pela repetição (o verso "Em relação a isso" alinhava as cinco estrofes); pelas rimas (isso/dito; imitação/solidão/ mão; caneta/poeta/gaveta; solidão/chão; dizer/ser; ciência/ convergência) e pela pontuação aberta (há apenas duas ocorrências de ponto final). A prevalência de versos curtos favorece esse movimento solicitando à voz uma maior velocidade. A performance vocal precisa estar atenta a essa "convergência", pois ela não define apenas o sentido, mas também o som do poema. Digamos que se trata da chave de escuta desse quase estudo de poesia, por ela, se alcança a entoação de cada verso, que, por seu turno, adquire uma feição harmoniosa com o conjunto da composição. Com isso, faz-se com que a imagem da voz se torne voz da imagem.
41. AMARAL, Ana Luísa.

Poesia reunida, 2005, p. 220. 
42. ARCHANJO, Neide. Todas as horas e antes, 2006b, p. 66.

43. VALERY, Paul. Le coup de dés: lettre au directeur des Marges, 1957, p. 623624. "Amo essa ausência de artifício. A voz humana parece tão bela interiormente, e pega o mais perto de sua origem, que os declamadores profissionais quase sempre me são insuportáveis, eles querem exaltar, interpretar, mas sobrecarregam, pervertem as intenções, alteram as harmonias de um texto; e colocam o seu lirismo no lugar do canto próprio das palavras arranjadas" (tradução nossa).
A terceira voz da primeira instância veste o ethos do outro, acomoda-se a uma máscara e finge o "eu" de uma alteridade. Configura-se no poema uma subjetividade que se descola da fixidez do "eu", nega sua natureza ambígua e se desloca em direção ao centro de outra interioridade. $O$ intérprete se vê diante de um desafio. Vejamos o que acontece no poema 17 do livro Quixote, tango, foxtrote, em que Neide Archanjo chama de "viajor" aquele que diz:

- Eu quero os caminhos encantados
que levam ao mar
e a presença de uma paz,
flor bem funda.
Por isso abandonei a minha casa.
Ando e aprendo que o mundo
é velho e novo a cada passo
e que tudo se liberta a cada instante. ${ }^{42}$

A relação do intérprete com a subjetividade configurada no poema deixa de ser imediata. O "eu lírico" simula uma voz. Ao dizer o poema, o vocalizador deve perceber a que conduziu o fingimento. É preciso perceber que a condensação fônica de "flor bem funda", o ritmo bem marcado dos últimos versos e a assonância toante de "Ando e aprendo que o mundo" adquirem uma nova dimensão porque estão associadas à determinada entoação. Entretanto, não se trata aqui de caracterizar o timbre, nem de dramatizar. Trata-se antes de verificar o que cada escolha representa para aquele eu-outro. Valéry comenta a voz neutra que Mallarmé usa para dizer seu "Lance de dados":

J'aime cette absence d'artifice. La voix humaine semble si belle intérieurement, et prise au plus près de sa source, que les diseurs de profession Presque toujours me sont insupportables qui prétendent faire valoir, interpréter, quand ils surchargent débauchent les intentions, altèrent les harmonies d'un texte; et qu'ils substituent leur lyrisme au chant propre des mots combinés. ${ }^{43}$

Como no poema, não se afigura uma personagem, corporificada por uma palavra autônoma, aparecendo apenas um fragmento de um ser, uma máscara efêmera, a que poderíamos chamar persona, emprestar a voz ao "viajor" significa assumir temporariamente esse ethos. É preciso tomar o cuidado para não sobrepô-lo com as escolhas da subjetividade do vocalizador, o que implicaria substituir o lirismo do poema pelo lirismo da interpretação. Dá-se apenas ligeira aparência da realidade dessa persona pelos limites impostos pelo próprio poema.

A segunda instância, das vozes para o "tu”, guarda em comum com a primeira instância a marcação gramatical da presença do sujeito. Também aqui podemos identificar três vo- 
zes: a voz para o sujeito singular, o "tu"; a voz para o sujeito pluralizado sob a forma do "vós"; e, por fim, a voz para um "tu" ou "vós" que aqui também traja - ou é trajado com - uma máscara. O que se modifica nessa instância é o efeito de sentido gerado pela interpelação do outro. $O$ gesto de se dirigir ao ouvinte, além de ampliar o impacto emocional, faz com que ele fique mais atento, despertado por palavras que são dirigidas à sua pessoa. A voz lírica institui seu interlocutor no poema, ao se dirigir a ele pelo modo imperativo, ao denotar sua presença nas formas verbais ou ao identificá-lo pelo vocativo. Essa presença do outro no dizer do poema lírico pode ser realizada também pela pergunta:

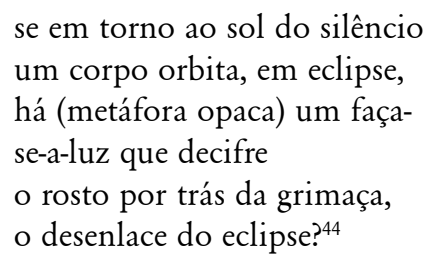

Nesse poema, o traço prosódico da construção em versos-pergunta impõe uma determinada inflexão. A indagação sobre a relação entre o sol do silêncio e o eclipse do corpo se instaura por uma intenção metafórica que sugere algo não somente a respeito da voz lírica, mas também do interlocutor a que ela se volta. Como se a interrogação fosse quase um desafio: é possível enxergar em mim, palavra silente, que faz grimaça, fingindo uma aparência, o disfarce de um rosto, talvez o de quem propõe a questão. Essa modalização interfere no que comumente se designa como tom do poema e que, na performance vocal, torna-se determinada entoação. Fruto inicialmente da linha melódica do verso, o tom também se caracteriza pelo conteúdo das imagens, pelas pausas e silêncios sugeridos pela pontuação e mesmo pela seleção vocabular. Se falar o poema possibilita o conhecimento de seu ritmo, este adquire possibilidades de sentido efetivo somente pela tonalidade que ajuda a compor.

Por sua construção, o exemplo de Roquette-Pinto aponta para as terceira e quarta instâncias, nas quais não aparece marca explícita do sujeito, este se desvenda antes pelo trabalho com a linguagem que por uma presença efetiva. $\mathrm{Na}$ terceira instância, manifestam-se "vozes sobre ele". "Ele" poderá ser um indivíduo, uma coisa, um acontecimento, uma paisagem. A subjetividade se posiciona diante de um objeto ou de um evento e fala dele. Nessa instância, manifestam-se duas vozes principais, uma que se qualifica pela conceitualidade, outra, pela narratividade. Vejamos como Manuel de Freitas apresenta "Charles Monroe", trazendo para dentro do poema elementos narrativos que o caracterizam:
44. ROQUETTE-PINTO, Claudia. Zona de sombra, 2000, p. 30 . 
45. FREITAS, Manuel de.

Portugal, 0, 2007, p. 57.

46. MACIEL, Maria Esther.

Poéticas da lucidez: notas sobre os poetas críticos da modernidade, 1994, p. 80.

47. ARCHANJO, Neide. Todas as horas e antes, 2006a, p. 234.
Pegou no pênis

e numa navalha antiga

que devia ter barbeado o avô

e foi-se despegando dele

(não do avô, morto e enterrado).

Meteu depois os resíduos

em envelopes lacrados

que fez seguir para pessoas

que nunca na vida encontrara

Tudo isto, pensou, deve

ter como Deus

um sentido incontornável.

Convidaram-no para o jornal das oito. ${ }^{45}$

Percebemos com que proximidade somos colocados diante da figura cujo nome é título do poema. Proximidade apenas aparente. Nosso contato com os eventos narrados se dá por mediação modal exercida por uma voz que sugere saber como Charles agiu e "pensou", mas que nos oferece apenas uma amostra. Em composições como essa, a performance vocal corre o risco de substituir o ritmo do poema pelo andamento da narração de uma história. Por isso, é preciso lembrar a constituição do verso, que impõe uma quebra, uma respiração, que rompe a sintaxe da língua. O mais importante não são as ações de Charles, mas o modo como elas são postas entre sons e silêncios. Nesse sentido, a pausa que se segue a "um sentido incontornável” não tem a mesma duração das que separam as estrofes anteriores, ela ganha tempo, ganha peso, reforçando o sentido do verso que a antecede e introduzindo o último, que se destaca do conjunto.

$\mathrm{Na}$ quarta e última instância, dizem as "vozes da ausência”. Nos poemas que suscitaram essa distinção, o sujeito se dilui, se ausenta, desaparece da malha textual, e cede lugar à linguagem. ${ }^{46} \mathrm{~A}$ subjetividade se manifesta de três formas principais: pela apropriação de textos de outra ordem de significação; pela teatralização; ou pela experimentação de linguagem. Em Neide Archanjo, encontramos um exemplo da primeira forma, quando surge no meio do livro: "Cópia da fatura de um santeiro (original arquivado na Torre do Tombo), apresentada no ano de 1853, de uma reparação que fez na capela de Bom Jesus de Braga”. ${ }^{47}$ A lista que aparece depois dessa identificação se instala entre o verdadeiro e o inventado. Poderíamos verificar no arquivo mencionado a existência do documento, mas isso de fato não importa. O que ganha dimensão é o uso que a criação poética faz de um texto outro, que tem, digamos, uma existência sonora própria, cujos limites são postos, a princípio, muito mais pela necessidade de cumprir uma determinada fun- 
ção pragmática que pelo trabalho com o som das palavras com vistas à produção de um ritmo específico. Para lidar com essa dificuldade, é preciso considerar que o simples fato de integrar uma coletânea de poemas torna esse texto parte do mundo de uma subjetividade, que está presente, apesar de lançar mão de subterfúgios que a ocultam. Dessa forma, as linhas adquirem o estatuto de verso, e as palavras assumem a cadência que lhes dá a alternância entre sílabas fortes e fracas. $\mathrm{O}$ mesmo se aplica a estes dois poemas de Francisco Alvim, nos quais o sujeito teatraliza sua própria ausência, sem que, no entanto, se elimine o princípio subjetivo organizador.

\section{MÃOS TRÊMULAS \\ - Você quer um? \\ - Não, não adianta. ${ }^{48}$}

\section{SOZINHA}

- Vá ao cinema

- Com quem? ${ }^{\text {49 }}$

Nesses poemas, deparamo-nos com uma dramatização do lírico, ${ }^{50}$ que produz uma subjetividade teatralizada, ao posicionar vozes em diálogo. É preciso, no entanto, perceber que se trata de uma simulação. Estão ali postos versos de um poema, e não linhas transcritas de uma conversa. O ritmo transformado em entoação funciona na composição como um todo. Ademais, no caso de Francisco Alvim, a presença de uma subjetividade, mesmo que não marcada, é sugerida pelo recorte das cenas, que indicia um ato de focalização, e mesmo pelos títulos, que completam, modificam ou comentam o que é dito no corpo do poema.

Em todas as instâncias, o trabalho com o significante apresenta por si mesmo um movimento organizador impulsionado pelo princípio subjetivo. Das manifestações do sujeito expresso na enunciação lírica a manifestações da subjetividade sem demarcação nítida, o jogo com a linguagem adquire crescente evidência no espaço do poema. Nesse sentido, tanto em "Sopro", em que a pessoa poética se instala explicitamente pelas formas verbais e pronominais, quanto nos versos dialogados de Alvim, a seleção vocabular, as escolhas formais, a pauta rítmica e a formação das imagens caracterizam a subjetividade que ali se afigura. No entanto, se nem o emissor do enunciado poético, nem seu interlocutor ou o objeto da percepção subjetiva comparecem ao tecido textual, mesmo que de forma ambígua, a materialidade linguística aberta à intervenção criativa se torna ela mesma encarnação da subjetividade.
48. ALVIM, Francisco. Poesias reunidas, 1988 , p. 89.

49. Ibidem, p. 111.

50. SÜSSEKIND, Flora. Seis poetas e alguns comentários, 1989, p. 191. 
$\mathrm{Na}$ quarta instância, o elemento subjetivo se instaura nos poemas não pela significação definidora das palavras, mas por sua força fônica e potencialidade semântica. Essa configuração concede à performance maior liberdade de intervenção, porque com ela o lugar lírico é ocupado pelo jogo mágico da linguagem que, embora tenha regras e limites, não está condicionado pela presença subjetiva explícita. Dessa forma, a voz do intérprete participa da matéria poética sem estar obsedada pelas demandas que existem nas outras instâncias. Na primeira delas, em quaisquer manifestações, a voz se entrega à expressão de um sujeito que ocupa o centro da significação. O intérprete exerce o ethos configurado no poema e precisa se manter atento para não cometer excessos, contrários ao que está posto pela marcação do "eu" nos sentidos e nos sons das palavras. $\mathrm{Na}$ segunda instância, a presença do outro orienta a conduta daquele que diz, porquanto sua voz, mesmo se a identidade do interlocutor não for demarcada, coloca-se perante uma audiência, com que estabelece uma relação - sugerida pelo próprio poema. Na terceira instância, o objeto de deslinde conceitual ou narrativo avança ao primeiro plano. Executar vocalmente o poema é, nesse caso, incorporar determinada perspectiva e dar a conhecer pela voz o que ou como se vê, ou ainda o que se presencia na posição de uma subjetividade. A distribuição em instâncias atende a fins de sistematização teórica, a divisão, no entanto, não define compartimentos estanques e incomunicáveis, como fica claro quando verificamos a hesitação entre elas.

Se o movimento rítmico de um poema somente é compreendido no conjunto de seus versos, esse princípio não é menos válido para a configuração do princípio subjetivo. Vejamos como as duas primeiras estrofes do poema "Canto das Letras" de Fiama Hasse revestem-se de uma subjetividade que é modificada no último verso da segunda estrofe e se subverte completamente no início da estrofe final:

DALETH é a porta eclusa para entrar no Espírito da Letra, assim o som afeiçoou a pena (no antigo sentido de afeição) à mão segundo o ouvido.

DALETH é o vitral da casa, pensado como pórtico da Luz porque o sentido move-se nas letras oculto e desoculto pelo Som.

NUN era o peixe do mercúrio magnífico e submerso antes, e porque o Amor é água antes do fogo NUN foi o sinal inscrito, purificado e recto.

KAPH recebe DALETH e NUN 
com o dom de submissão que cabe ao espírito e às nossas mãos.

Pegai nas sete letras da açucena brilhando neste Meio-dia de luz, ó meu sangue, que me precedes em mim, antes de Eu mesma, e no sangue meu materno que no retrato sépia espera ser adornado de açucenas hoje. ${ }^{51}$

Nas duas primeiras estrofes, encontramos uma voz que se pronuncia sobre duas letras dos alfabetos semíticos, "DALETH” e "NUN". Ao apresentá-las com um gesto entre narrativo e conceitual, a voz coloca-nos diante de uma subjetividade de terceira instância. No verso final da segunda estrofe, a presença do pronome "nossas" instaura um sujeito pluralizado de primeira instância, para, na última estrofe, iniciada com um verbo no imperativo, surgir o gesto de interpelação, característico da segunda instância. $O$ interlocutor identificado pelo vocativo, "ó meu sangue", não vem da exterioridade, ele habita o próprio espaço lírico. O pronome possessivo "meu", seguido de outras formas pronominais (“me”, “mim”, "Eu”), instala por fim a presença evidente do sujeito, que, além de enunciar-se textualmente, baliza-se, ao declarar seu gênero, "Eu mesma”, e ao associá-lo à maternidade, "e no sangue meu materno”. Diante de uma configuração tão intricada de vozes, o intérprete, em sua performance, terá de considerar o princípio subjetivo articulado no conjunto. Embora os versos iniciais não demarquem o sujeito, este aparece antes do poema terminar e a sua presença é determinante para o tom que se comunica pelo dizer.

A dimensão sonora da poesia é em algum momento esquecida, em razão do papel hegemônico desempenhado pela mídia escrita. Ela não é, no entanto, suprimida. A importância do som em articulação com o sentido para a compreensão e apreciação do texto poético é inegável. O caráter performativo da leitura de poesia se torna evidente pelo gesto de vocalização. Se quando leio, "sou o sujeito de pensamentos diferentes dos meus" e "minha consciência se comporta como se fosse a consciência de outro", ${ }^{52}$ quando vocalizo, torno público o pacto subjetivo que se estabelece entre mim e o texto.

O homem que lê de viva voz se expõe totalmente. Se não sabe o que lê, ele é ignorante de suas palavras, é uma miséria, e isso se percebe. Se se recusa a habitar sua leitura, as palavras tornam-se letras mortas, e isso se sente. Se satura o texto com sua presença, o autor se retrai, é um número de circo, e isso se vê. $O$ homem que lê de viva voz se expõe totalmente aos olhos que o escutam..$^{53}$
51. BRANDÃO, F. H. P. Obra breve: poesia reunida, 2006, $\mathrm{p}$. 577.

52. POULET, George. A crítica e a experiência de interioridade, 1976, p. 76.

53. PENNAC, Daniel. Como um romance, 2008, p. 149. 
54. JAKOBSON, Roman. Linguística e poética, 1974, p. 122.

55. ZUMTHOR, Paul. Performance, recepção, leitura, 2007, p. 87.
O sujeito vocalizador precisa saber o que diz. Atingir uma performance que vivifica de fato a voz do poema implica associar à subjetividade nele configurada a subjetividade própria de uma fonia, sem que esta, no entanto, usurpe o lugar daquela, pois um jogo nunca acontece sem regras. $O$ pacto entre as subjetividades se consolida por um processo de identificação.

Jakobson define a língua como código global constituído por inúmeros subcódigos. ${ }^{54}$ Essa afirmação, articulada à sistematização das funções da linguagem apresentada pelo linguista russo e também às conclusões obtidas com a pesquisa, nos conduziu à seguinte reflexão sobre a natureza subjetiva da poesia. Há por trás da composição de um poema uma subjetividade que se constitui pela correalização de códigos: o código da língua, seu sistema léxico-sintático, que é patrimônio de uma cultura, situada num espaço e num tempo, mas nos limites do poema adquire um funcionamento outro; o código do poeta, que se cria com base na mitologia, história e memória do sujeito empírico e surge nos versos como conhecimento evocado; e, por fim, o código da obra, o qual se caracteriza, no conjunto de textos produzidos, pela historicidade literária, pela recorrência de imagens, pelos usos vocabulares, pelo padrão rítmico e, acima de tudo, pela configuração do princípio subjetivo.

O vocalizador se identifica a esses códigos para ativar a dimensão comunicativa da poesia. Se essa dimensão se revela pela concretização dos códigos da língua, do poeta e da obra no poema, pela prática vocal de poesia, ela se atualiza pela matéria própria de uma vocalidade. Como diz Zumthor, "a leitura do texto poético é escuta de uma voz. O leitor, nessa e por essa escuta, refaz em corpo e em espírito o percurso traçado pela voz do poeta: do silêncio anterior até o objeto que lhe é dado, aqui, sobre a página" ${ }^{55}$ Desse modo, camadas que significam na obra poética se mantêm, no texto escrito, apenas como virtualidade, mas na performance de uma voz, como emanação de um corpo, ganham viva realidade. 


\section{Referências}

ADLER, J. Mortimer; VAN DOREN, Charles. $A$ arte de ler. Trad. José Laurentino de Melo. Rio de Janeiro: Agir, 1974.

AGAMBEN, Giorgio. O autor como gesto. In: Profanações. Trad. Selvino José Assmann. São Paulo: Boitempo, 2007, p. 55-63.

ALVIM, Francisco. Poesias reunidas:1968-1988. São Paulo: Duas Cidades, 1988.

AMARAL, Ana Luísa. Poesia reunida: 1990-2005. Vila Nova de Famalicão: Edições Quase, 2005.

ARCHANJO, Neide. Todas as horas e antes: poesia reunida, volume 1. Organização de Maria Celeste Garcia. 2. ed. São Paulo: A Girafa Editora, 2006a.

ARCHANJO, Neide. Todas as horas e antes: poesia reunida, volume 2. Organização de Maria Celeste Garcia. 2. ed. São Paulo: A Girafa Editora, 2006b.

BANDEIRA, Manuel. A versificação em língua portuguesa. In: Seleta de prosa. Rio de Janeiro: Nova Fronteira, 1997, p. 533-558.

BERRY, Francis. Poetry and the physical voice. New York: Oxford University Press, 1962.

BOSI, Alfredo. Frase: música e silêncio. In: $O$ ser e o tempo da poesia. 6. ed. São Paulo: Companhia das Letras, 2000.

BRANDÃO, Fiama Hasse Pais. Obra breve: poesia reunida. Lisboa (Portugal): Assírio \& Alvim, 2006.

BRIK, Ossip. Ritmo e sintaxe. In: TOLEDO, Dionísio de Oliveira. (Org.). Teoria da literatura: formalistas russos. Trad. Ana Mariza Ribeiro; Maria Aparecida Pereira; Regina L. Zilberman e Antônio Carlos Hohlfeldt. Porto Alegre: Globo, 1971, p. 131-139.

CARDOSO, Glaucio Varella. Poesia lida, poesia falada: poesia, performance e recepção - aspectos teóricos e práticos. 2009. 110 f. Dissertação (Mestrado em Literatura Brasileira) - Instituto de Letras, Universidade do Estado do Rio de Janeiro, Rio de Janeiro, 2009.

COHEN, Jean. Estrutura da linguagem poética. Trad. de Álvaro Lorencini e Anne Arnichand. São Paulo: Cultrix: Edusp, 1974. 
DUFRENNE, Mikel. O poético. Trad. Luiz Arthur Nunes e Reasylvia Kroeff de Souza. Porto Alegre: Globo, 1969.

ECO, Umberto. Lector in fabula: a cooperação interpretativa nos textos narrativos. Trad. Attílio Cancian. São Paulo: Perspectiva, 2008.

ELIOT, T. S. As três vozes da poesia. In: A essência da poesia. Trad. Maria Luiza Nogueira. São Cristovão: Artenova, 1972, p. 129-147.

FRIEDRICH, Hugo. Estrutura da lírica moderna. Trad. Marise Curioni. São Paulo: Duas Cidades, 1978.

GOLDSTEIN, Norma Seltzer.Versos, sons, ritmos. 3. ed. São Paulo: Ática, 1986.

HAMBURGER, Käte. A lógica da criação literária. Trad. Margot P. Malnic. 2. ed. São Paulo: Perspectiva, 1986.

HEGEL, Georg W. F. Curso de estética: o sistema das artes. Trad. Álvaro Ribeiro. 2. ed. São Paulo: WMF Martins Fontes, 2010.

HUIZINGA, J. Homo ludens: o jogo como elemento da cultura. Trad. João Paulo Monteiro. 4. ed. São Paulo: Perspectiva, 1996.

JAKOBSON, Roman. Linguística e poética. In: Linguística e comunicação. Trad. Izidoro Blikstein e José Paulo Paes. São Paulo: Cultrix, 1974, p. 118-162.

MACIEL, Maria Esther. Poéticas da lucidez: notas sobre os poetas críticos da modernidade. Revista de Estudos de Literatura. Belo Horizonte, v. 2, p. 75-96, out. 94. Disponível em: http://www.letras.ufmg.br/poslit/08_publicacoes_txt/ ale_02/ale02_memob.pdf. Acesso em: 15 maio 2011.

MAINGUENEAU, Dominique. A propósito do ethos. In: MOTTA, Ana R.; SALGADO, Luciana (Org.). Ethos Discursivo. São Paulo: Contexto, 2008, p. 11-29.

MARTELO, Rosa Maria. Reencontrar o leitor. Relâmpago: Revista de Poesia, Lisboa, n. 12, 2003, p. 39-52.

MOISÉS, Massaud. Ritmo. In: Dicionário de termos literários. 5. ed. São Paulo: Cultrix, 1988.

PAZ, Octavio. Verso e prosa In: O arco e a lira. Trad. Olga Savary. 2. ed. Rio de Janeiro: Nova Fronteira, 1982, p. 82-118.

PENNAC, Daniel. Como um romance. Trad.Leny Werneck. Porto Alegre: L\&PM; Rio de Janeiro: Rocco, 2008. 
PINSKY, Robert. The sounds of poetry: a brief guide. New York: Farrar, Straus and Giroux, 1998.

POULET, George. A crítica e a experiência de interioridade. In: DONATO, Eugênio; MACKSEY, Richard. A controvérsia estruturalista: as linguagens da crítica e as ciências do homem. São Paulo: Cultrix, 1976.

ROQUETTE-PINTO, Claudia. Zona de sombra. 2. ed. Rio de Janeiro: Sete Letras, 2000.

STERZI, Eduardo. Da letra à voz, Alea, Rio de Janeiro, v. 14/2, p. 165-179, jul.-dez. 2012.

SÜSSEKIND, Flora. Seis poetas e alguns comentários. Revista USP, São Paulo, v. 2, p. 175-192, jun.-ago. 1989. Disponível em: http://www.usp.br/revistausp/02/25-flora.pdf. Acesso em: 13/06/2011.

VALERY, Paul. Le coup de dés : lettre au directeur des Marges. In: Oeuvres. v. 1. Paris: Gallimard, 1957, p. 622-630.

Au hasard et au crayon. In: Oeuvres. v. 2. Paris:

Gallimard, 1960.

ZUMTHOR, Paul. A letra e a voz. A "literatura" medieval. Trad. Amálio Pinheiro e Jerusa Pires Ferreira. São Paulo: Companhia das Letras, 1993. Performance, Recepção, Leitura. Trad. Jerusa Pires

Ferreira e Suely Fenerich. 2. ed. São Paulo: Cosac Naify, 2007. Introdução à poesia oral. Trad. Jerusa Pires Ferreira, Maria Lúcia Diniz e Maria Inês de Almeida. Belo Horizonte: Ed. UFMG, 2010. 
